STUDIA EDUKACYJNE NR 50/2018

MAGDA KARKOWSKA

Uniwersytet Łódzki

\title{
TERAPEUTYCZNE ASPEKTY WYWIADU NARRACYJNEGO W PERSPEKTYWIE PROWADZENIA BADAŃ BIOGRAFICZNYCH
}

\begin{abstract}
Karkowska Magda, Terapeutyczne aspekty wywiadu narracyjnego w perspektywie prowadzenia badan biograficznych [Therapeutic Aspects of a Narrative Interview in the Persepctive of Biography Studies]. Studia Edukacyjne nr 50, 2018, Poznań 2018, pp. 107-120. Adam Mickiewicz University Press. ISSN 1233-6688. DOI: $10.14746 /$ se.2018.50.7

The article is devoted to an attempt to present a biographical approach in pedagogical research, taking into account not only exploratory but also therapeutic functions of narrative interviews. The reflections focus of looking for the answer to the question: whether and to what extent telling a story of one's life (especially marked by traumatic experiences) may contribute to integrating the past and the present, increasing self-awareness, and thus (re-)constructing the narrator's identity? I ask a question about the conditions to be met in order for the narrator to realize the limitations posed by the past and next to overcome the crisis by pointing out the main motives of action, epiphanies, crises, or breakthrough moments.
\end{abstract}

Key words: Interview, narrative, therapeutic influence

\section{Kilka słów o celach badań biograficzno-narracyjnych}

Badania biograficzne bywają zazwyczaj rozpatrywane jako odmiana studium indywidualnych przypadków, a zbliżone do nich określenia to: badania psychobiograficzne (Charlotte Bühler) ${ }^{1}$, badania biograficzno-narracyjne (Urbaniak-Zając) ${ }^{2}$, badania narracyjne (Kubinowski) ${ }^{3}$ oraz podejście biograficzne (Lalak) $)^{4}$

${ }^{1}$ Ch. Buhler, Bieg życia ludzkiego, przekł. E. Cichy, J. Jarosz, Warszawa 1999.

${ }^{2}$ D. Urbaniak-Zając, E. Kos, Badania jakościowe w pedagogice: wywiad narracyjny i obiektywna hermeneutyka, Warszawa 2013.

${ }^{3}$ D. Kubinowski, Jakościowe badania pedagogiczne: filozofia, metodyka, ewaluacja, Lublin 2010.

${ }^{4}$ D. Lalak, Życie jako biografia: podejście biograficzne w perspektywie pedagogicznej, Warszawa 2010, s. 15 . 
Celem badań biograficznych jest zazwyczaj rekonstrukcja najważniejszych wątków w narracyjnej opowieści, podejmowana w celu przybliżenia procesów kształtowania tożsamości jednostkowej. Jak zauważa Teodor Schulze, rozróżnienie między rodzajami badań biograficznych czy narracyjno-biograficznych opiera się na koncentracji bądź zewnętrznym oglądzie (analiza przebiegu życia, jego etapów, cykli, pytanie o społeczne uwarunkowania biografii), bądź na wewnętrznej analizie przeżyć i doświadczeń badanych ${ }^{5}$. Jeśli przyjmiemy powyższe założenia dotyczące przedmiotu i celu badań, badania biograficzne nie powinny być uznawane za synonim badań narracyjnych. Jeśli natomiast zwrócimy uwagę na sposób przeprowadzania omawianych badań, wówczas procedura gromadzenia materiałów i sposoby ich analizowania tak $\mathrm{w}$ badaniach narracyjnych, jak i biograficznych są w zasadniczych punktach zbieżne.

Kolejnym, często spotykanym $\mathrm{w}$ literaturze przedmiotu określeniem jest "metoda biograficzna/perspektywa biograficzna”. Jak zauważa Danuta Urbaniak-Zając, trudno mówić o jednej, spójnej metodzie biograficznej. Przeciwnie - podejść o tym charakterze jest wiele ${ }^{6}$. Wynika to zarówno z wielości perspektyw biograficznych (biografia może być rozumiana jako tekst czy opowieść, jako proces wiodący do kształtowania tożsamości jednostkowej, jako społeczna konstrukcja, w ramach której poszukujemy prawidłowości jej przebiegu czy typów biograficznych, a także jako forma komunikacji), a co za tym idzie - celów jakie stawia sobie badacz, czy sposobu w jaki traktowane są dane pochodzące $z$ biografii. Obydwie perspektywy postrzegania biografii potraktowane zostaną jako punkt wyjścia dla poniższych rozważań.

To, czym w istocie jest metoda biograficzna, czy szerzej - pewna perspektywa badawcza zajmująca się biografiami, zależy także od tego, jak badana jest biografia, co relacjonuje ${ }^{7}$ oraz jaki model badania biografii uznamy za wyjściowy ${ }^{8}$.

${ }^{5}$ D. Urbaniak-Zając, Biograficzna perspektywa badawcza, [w:] Uczenie się z biografii innych, red. E. Dubas, W. Świtalski, Łódź 2011, s. 9-16.

${ }^{6}$ Tamże, s. 12.

${ }^{7} \mathrm{~W}$ istocie jest to pytanie o związek między biograficznym podmiotem a otaczającą rzeczywistością, życiem. Każdy z nas w jakimś stopniu jest producentem, jak i produktem własnej biografii. Ponadto, biografia nie ma charakteru linearnego (Ecarius). Składają się nań warstwy. Istotne jest pewne kontinuum czasowe - to co było, ale i to co jest i to co będzie (Schulze); Za: D. Urbaniak-Zając, Biograficzna perspektywa badawcza, s. 9-16.

${ }^{8}$ Kwestią niezwykle istotną jest dyskusja między zwolennikami podejścia emicznego bazującego na analizie języka badanych oraz etycznego - opartego na obserwacji zachowań reprezentantów określonej kultury czy społeczności (grupy). W przytoczonych wyżej modelach badań albo zakłada się, że język i sposób wypowiedzi stanowi reprezentację świata życia badanych, albo odwrotnie - drogą obserwacji poszukuje się różnic między tym co badani mówią a tym jak się zachowują. Podejście emiczne i etyczne, wypracowane przez antropologów kulturowych, odpowiada wewnętrznemu i zewnętrznemu traktowaniu danych empirycznych (Schulze) w badaniu biograficznym. 
Niezwykle istotną cechą podejścia biograficznego jest fakt, że pozwala ono na poznanie sposobu, w jaki przeżywane bywa jednostkowe doświadczenie. Warunkiem jest jego istotność dla narratora, czy je pamięta, próbuje odtworzyć i - co niemniej ważne - gotów jest podzielić się swoimi wspomnieniami. Aby opowieść biograficzna stanowiła wartościowy materiał badawczy, powinna pozwalać dotrzeć do tego, w jaki sposób otaczająca rzeczywistość wywarła wpływ na świadomość, postawy, dążenia, czy opinie ludzi, będących uczestnikami określonych wydarzeń. Zgodnie z zasadą współczynnika humanistycznego ${ }^{9}$, w badaniach biograficznych istotna jest subiektywnie postrzegana rola i znaczenie kontekstu w kształtowaniu biografii jednostkowej. Aby ową biografię, czy częściej jej kluczowe wątki, poznać, badacze posługują się wywiadem.

\section{Wywiad jako spotkanie}

Amerykański socjolog Erving Goffman zauważa, że istotny wpływ na budowanie każdej interakcji wywierają zarówno pewne ponadczasowe reguły, zwane też rytuałami sytuacyjnymi, jak i kontekst kulturowy oraz status uczestników spotkania, które to czynniki pozwalają zmieniać i modyfikować jego przebieg. Przestrzeń życia społecznego metaforyzowana jest jako dramat, gra i rytuał. Wywiad, kierowana rozmowa jest w ujęciu goffmanowskim pewną sytuacyjną grą, podczas której uczestnicy muszą rozstrzygnąć, w jakim stopniu gotowi są utrzymywać zarówno własne emocje, jak i czynniki zewnętrzne pod kontrolą, aby ich spotkanie stanowiło samoistny świat, zogniskowany na określonych zagadnieniach. Kontrola taka opiera się na umiejętności selekcji, oddzielenia elementów nieznaczących od istotnych - takich, które budują sens owego spotkania. Musimy jednak pamiętać, że podczas w miarę spontanicznej rozmowy, jaką jest wywiad, nie są to działania świadome, a istotną rolę w podtrzymywaniu definicji sytuacji pełnią emocje rozmówców. Jest tu możliwe całe spektrum zachowań pomiędzy oddaniem się we władanie roli a dystansem do niej. W pierwszej sytuacji rozmowa i omawiane zagadnienia pochłaniają rozmówcę na tyle, że w nikłym stopniu kontroluje on sytuację, obraz samego siebie, czy wrażenie wywierane na osobie prowadzącej wywiad. W drugim przypadku, dystansując się od roli badanego, może on sprawiać wrażenie osoby w ogóle nie zaangażowanej w dyskusję i w pełni kontrolować fakty, znaczenia, a przede wszystkim poziom szczerości własnych wypowiedzi. Dystans do roli, pojawiająca się refleksja, podobnie jak wzajemna obserwacja rozmówców, pozwalają przewidzieć, a nierzadko ukierunkować linię działania partnera interakcji

${ }^{9}$ F. Znaniecki, Metoda socjologii, Warszawa 2008. 
Tym, co szczególnie interesuje Goffmana jest analiza sytuacji społecznej, mechanizmy „zagęszczania rzeczywistości”, koncentrowania się na określonym wycinku tejże, uwarunkowania komfortu i dyskomfortu jej uczestników, wynikające w dużym stopniu właśnie z możliwości kontrolowania sytuacji. Nie możemy bowiem zapominać, że to podmiotowość uczestników jest kluczowa, a nie sama definicja, nawet jeżeli reguły wspomnianej sytuacji są sztywne i z trudem podlegają negocjacji ${ }^{10}$.

\section{Wywiad - komunikacja i świat przeżywany}

Wywiad jest jedną z najczęściej stosowanych technik badawczych w badaniach jakościowych, przy czym pełni on nieco inną funkcję, aniżeli te prowadzone w paradygmacie badań ilościowych. Chodzi tu nie tyle o zbieranie opinii, co o rekonstrukcję znaczeń, jakie respondenci nadają rzeczywistości na poziomie poznawczym, emocjonalnym, czy moralnym. Istotne jest wydobycie ich $\mathrm{z}$ wypowiedzi badanego, stymulowanie wglądu we własne doświadczenia, który miewa nierzadko znaczenie terapeutyczne. Pozwala strukturyzować własne przeżycia, analizować je, nadawać im w perspektywie życia odpowiednią rangę, a w efekcie rozwijać samoświadomośćc ${ }^{11}$. Nie należy więc w badaniach, których przedmiotem są wspomnienia czy doświadczenia badanych sprowadzać wywiadu do „techniki gromadzenia danych", która zapewnia szybkie pozyskiwanie jednoznacznych wypowiedzi respondenta. Pod wpływem tematyzacji doświadczenia, to co nie było dotąd rozważane zostaje poddane refleksji, a werbalizacja i konceptualizacja własnego doświadczenia wspiera rozwój samoświadomości. Dobrze zadane pytania przyczyniają się do wzrostu wiedzy tematycznej i wytworzenia dobrej komunikacji opartej na pozytywnych interakcjach między zbierającym informacje a narratorem. Im bardziej uporządkowana jest sytuacja i przebieg wywiadu, tym łatwiej systematyzować i analizować informacje $\mathrm{z}$ niego pochodzące.

Proces komunikacji rozpoczyna się zetknięciem dwóch światów, dwóch subiektywnych rzeczywistości: tej reprezentowanej przez badacza i tworzonej przez badanych. Co mają one ze sobą wspólnego? Co je różni? Aby zainicjować proces komunikacji konieczne jest otwarcie się na drugiego człowieka, gotowość do przyjęcia jego perspektywy, oglądania świata jego oczyma i opisywania go jego językiem.

\footnotetext{
10 E. Goffman, Spotkania, przekł. P. Tomanek, Kraków 2010, s. 6 i n.
}

11 K. Rubacha, Metodologia badań nad edukacją, Warszawa 2008. 
Rozumienie każdej sytuacji interakcyjnej obejmuje kilka aspektów (językowy, kontekstualny, empatyczny, aksjologiczny) ${ }^{12}$ i od nich jest uzależnione. Nie inaczej bywa w sytuacji wywiadu.

Szczególnie istotne dla porozumienia się badacza i badanego w sytuacji wywiadu są aspekty kontekstualny, jak też empatyczny, bowiem umożliwiają wejście w strukturę świata przeżywanego, zrozumienie motywów, znaczeń i elementów konstruujących narrację, ale także emocji towarzyszących badanemu, śladów w jego psychice jakie pozostawiły omawiane wydarzenia.

Reasumując, efektywność komunikacji w wywiadzie uzależniona jest między innymi od:

- zrozumienia własnych wypowiedzi przez obydwie strony - badanego, jak i badacza;

- subiektywnej szczerości (zgodności tego co mówimy z tym jak myślimy i co czujemy - terapeuci nazywają tę cechę kongruencją);

- poprawności wypowiedzi na poziomie językowym - używania powszechnie przyjętych zwrotów i wyrażeń, które mają charakter uniwersalny;

- umiejętności stymulowania narracji przez badacza.

$\mathrm{W}$ stosunkowo niewielkim stopniu, w porównaniu z komunikowaniem codziennym, efektywność ta zależy od prawdziwości (czy prawomocności, inaczej zgodności z faktycznym stanem rzeczy) wypowiedzi badanego. Nie chodzi tu bowiem o koncentrowanie się na obiektywnych faktach, ale właśnie na znaczeniach jakie nadają im badani i sposobach w jakich funkcjonują one $\mathrm{w}$ ich doświadczeniu. Wywiad pozwala zagłębić się w wyjątkowość i typowość opowieści badanych, a droga do tak postawionego celu wiedzie poprzez wiedzę i umiejętności badacza nabyte w praktyce badawczej.

\section{Wywiad narracyjny - próba charakterystyki}

Twórcą wywiadu narracyjnego jest Fritz Schútze. Główne założenie, na jakim się opierał, mówi, że poznanie ludzkiego życia możliwe jest dzięki interpretacji tego, co nam się przydarza, codziennych doświadczeń i wydarzeń jakie są naszym udziałem.

Podstawą wywiadu narracyjnego jest opowiadanie o tym co się wydarzyło. Sama narracja jest jednak rozumiana szerzej: jako retrospektywne tworzenie znaczeń, nadawanie kształtu przeszłym doświadczeniom, ich porządkowanie. W wywiadzie narracyjnym chodzi zatem o coś więcej niż o retrospekcję, narracja staje się sposobem rozumienia działań własnych oraz

${ }^{12}$ H. Retter, Komunikacja codzienna w pedagogice, przekł. M. Wojdak-Piątkowska, oprac. B. Śliwerski, Gdańsk 2005, s. 25 i n. 
podejmowanych przez inne osoby, organizowaniem zdarzeń i obiektów w znaczącą całość, ich łączeniem ze sobą ${ }^{13}$. Schútze wyróżnił dwie odmiany wywiadu narracyjnego:

- narracyjny wywiad ekspercki;

- wywiad autobiograficzno-narracyjny.

$\mathrm{W}$ drugiej wersji bywa on utożsamiany $\mathrm{z}$ otwartym wywiadem pogłębionym (IDI), ale też z wywiadem swobodnym, nieukierunkowanym, w wersji jaką opisuje Steinar Kvale ${ }^{14}$.

Jak zauważa Susan Chase, narrację rozumieć można jako przyglądanie się konsekwencjom działań i zdarzeń na przestrzeni czasu ${ }^{15}$. Ta sama autorka wymienia pięć podejść do wywiadu narracyjnego:

- psychologowie narracyjni starają się uchwycić związki między relacjami jednostek z przeszłych wydarzeń, w których uczestniczyli, a jakością ich życia. Inaczej mówiąc, zakładają oni, że sposób opowiadania historii oddziałuje na zachowania podmiotów ją opowiadających. $W$ toku narracji mamy więc do czynienia z kształtowaniem samoświadomości narratora [przyp. - M.K.];

- socjologowie dostrzegają złożony i wielopoziomowy charakter narracji, traktując ją jak przeżywane doświadczenie. Wywiad narracyjny jest szansą, a zarazem sposobem jej uporządkowania;

- etnometodolodzy podkreślają rolę języka i jak za jego pomocą wydobywany jest $\mathrm{z}$ narracji sens, zawarty $\mathrm{w}$ tym co, a także jak mówią narratorzy o tle historycznym i kulturowym wydarzeń, które są przedmiotem narracji;

- antropolodzy podkreślają zarówno rolę narratora jak i badacza. W wywiadzie narracyjnym traktowanym jako spotkanie ważne są obydwie osoby i ich wypowiedzi;

- autoetnografowie uznają, że ważne życiowo momenty oraz znaczące wydarzenia wpisane $w$ kontekst kulturowy i społeczny są przedmiotem nie wywiadu, a własnych narracji.

$\mathrm{W}$ pozyskiwaniu materiału badawczego $\mathrm{w}$ drodze wyraźnie ukierunkowanej rozmowy, której podstawą są minione, nierzadko trudne, przeżycia narratora, kluczowe wydają się zarówno podejście psychologiczne jak i etnometodologiczne, ale też antropologia spotkania, uwypuklająca głębię wzajemnych interakcji narratora i badacza, z podkreśleniem tego, co dzieje się w samej przestrzeni komunikacji, ściśle wiążąc się z przedmiotem rozmowy. Nie możemy zapominać, że owo oprowadzanie po własnym życiu, odpowia-

${ }^{13}$ E. Januszewska, Wywiad biograficzny i metoda biograficzna - perspektywa badań jakościowych, [w:] Dziecko czeczeńskie w Polsce: między traumą wojenną a doświadczeniem uchodźstwa, Torun 2010.

14 S. Kvale, Interviews: wprowadzenie do jakościowego wywiadu badawczego, przekł. i oprac. S. Zabielski, Białystok 2004.

15 S. Chase, Wywiad narracyjny - wielość perspektyw, podejść, głosów, [w:] Metody badań jakościowych, t. 2, red. N. Denzin, Y. Lincoln, Warszawa 2009, s. 24-25. 
dające raczej koncepcji „podróżnika” niż „górnika” (Kvale) ${ }^{16}$, nie zawsze musi opierać się na ustalonych pytaniach, ich kolejności, jednak musi mieścić się w ustalonym zakresie problematyki. Narracjami bowiem są tylko te opowieści, które mają uchwytny początek, po którym następuje opis powiązanych ze sobą wydarzeń, ale i wyraźnie zaznaczony koniec, pewną granicę między tym co wspominane a nadawanym temu znaczeniom.

Wśród cech wywiadu narracyjnego przytaczanych przez Teresę Bauman najistotniejszą rolę $\mathrm{w}$ stymulowaniu narracji wydają się mieć współzależność (spotkanie i będąca jego podstawą rozmowa zmienia obydwie osoby w nią zaangażowane), integralność (angażowanie się w sytuację wywiadu całym sobą wymaga ustalenia granicy szczerości oraz intymności w wypowiedziach i reakcjach, obejmuje także gotowość badacza, aby jednocześnie słuchać, myśleć i mówić), a także wspólnota (duchowa więź nawiązująca się dzięki atmosferze spotkania i dialogu ${ }^{17}$. Są one szczególnie ważne jeśli założymy, że celem wywiadu narracyjnego jest opisanie nierzadko traumatycznych doświadczeń, uporządkowanie ich, wzbudzenie refleksji i stymulowanie wewnętrznej przemiany narratora - jego sposobu postrzegania siebie, swojej roli, a następnie ugruntowania oceny minionych wydarzeń.

\section{Terapeutyczne aspekty wywiadu narracyjnego}

Wywiad narracyjny uznawany jest za swoisty rodzaj pracy z drugim człowiekiem, to jest takiej, która, jak wcześniej wspomniano, obejmuje porządkowanie jego przeżyć, doświadczeń i pobudzanie do autorefleksji, ale też odtwarza pewną procesualność biograficznego doświadczenia. Jak zakłada Hubert Hermans ${ }^{18}$, istnieje homologia między sposobem, w jaki organizowane są doświadczenia w życiu a strukturą biograficznej narracji. Zazwyczaj fazy biografii są odtwarzane $\mathrm{w}$ strukturze narracji w takim samym porządku, $\mathrm{w}$ jakim następowały $\mathrm{w}$ życiu. Istotnymi cechami narracji uwzględnianymi przez wywiad o takim charakterze są:

- procesualność (zjawiska uchwycone zostają na pewnym kontinuum: powstanie-rozwój-zanikanie, nie zaś jako statyczny fakt. Istnieją jednak i tacy narratorzy, którzy wydobywają na plan pierwszy te aspekty wypowiedzi, które wydają się im najistotniejsze, najsilniej ich określają, są elementem autodefinicji lub z innych względów mają istotne znaczenie - wówczas zada-

${ }^{16}$ S. Kvale, Interviews: wprowadzenie.

17 T. Bauman, T. Pilch, Zasady badań pedagogicznych: strategie ilościowe i jakościowe, Warszawa 2001.

${ }^{18}$ H.J. Hermans, E. Hermans-Jansen, Autonarracje - tworzenie znaczeń w psychoterapii, Warszawa 2000. 
niem badacza jest również poszukiwanie odpowiedzi, z jakiego powodu tak się dzieje i w jaki sposób modyfikuje to czy uzupełnia sens narracji [przyp. - M.K.]);

- dynamika (przemiany biograficzne wynikające z uwikłania narratora w tło historyczne i społeczne, rozumiane jako element środowiska czy szerzej - kultury pewnej społeczności, czy grupy, której był/jest członkiem);

- ciągłość (mimo zmian i wszelkich zwrotów akcji narracja dotyczy wciąż biografii tej samej osoby, składa się na proces konstruowania tożsamości jednostkowej $)^{19}$.

Wywiad narracyjny jako pewien rodzaj interakcji, a zarazem forma komunikowania nie jest - jak zauważa Marek Czyżewski ${ }^{20}$ - aktem parezji, a tym bardziej wyznaniem czy spowiedzią, a mimo to ma walor oczyszczenia, dążenia ku prawdzie, ku samemu sobie ${ }^{21}$.

Jako zdarzenie interakcyjne i spotkanie dwójki ludzi, podczas którego nierzadko dochodzi do szczerej, obfitującej w niełatwe dla narratora wspomnienia, wywiad narracyjny ma wiele wspólnego z sesją psychoterapeutyczną. Cechą wspólną jest tu niewątpliwie dobrowolny akt odsłonięcia przed drugą osobą, ujawnienia i analizowania wspomnień, emocji. Jednak$\dot{z}$, terapeuta $\mathrm{w}$ przeciwieństwie do badacza-biografa jest profesjonalnie przygotowany na zetknięcie z silnymi emocjami i potrafi właściwie je spożytkować. Także pacjent ma świadomość, że mogą się one pojawić i w formie terapeutycznego kontraktu wyraża zgodę na zetknięcie z emocjonalnie trudnymi sytuacjami.

Tabela 1 ilustruje różnice $\mathrm{w}$ umiejętnościach interpersonalnych między osobą prowadzącą wywiad narracyjny a psychoterapeutą.

Umiejętności interpersonalne badacza i psychoterapeuty

\begin{tabular}{|c|c|}
\hline $\begin{array}{c}\text { Prowadzacy } \\
\text { wywiad biograficzny } \\
\text { (narracyjny) }\end{array}$ & Psychoterapeuta \\
\hline $\begin{array}{c}\text { - empatyczne } \\
\text { słuchanie }\end{array}$ & $\begin{array}{c}\text { - umiejętność budowania relacji opartej na bezpieczeństwie } \\
\text { i zaufaniu }\end{array}$ \\
\hline
\end{tabular}

${ }_{19}$ M. Czyżewski, Socjologia interpretatywna i metoda biograficzna: przemiana funkcji. Antyesencjalistyczne wątpliwości i sprawa krytyki, Przegląd Socjologii Jakościowej, 2017, IX, 4, s. 14-28.

20 Tamże, s. 25.

${ }^{21}$ Nakłada to na badacza pewne wymagania etyczne: nie wolno mu manipulować podmiotowością narratora, stosować moralnych pouczeń. Jak zauważa Gabriele Rosenthal, badaczowi nie wolno również burzyć mechanizmów obronnych narratora, trzeba zaakceptować fakt, że nie jest on gotów podjąć pewnych wątków. Badacz zobowiązany jest zapewnić narratorowi dyskrecję, poufność, prawo do odmowy odpowiedzi czy kontynuowania procedury wywiadu oraz wglądu do zgromadzonych danych. 


\begin{tabular}{|c|l|}
\hline - aktywne słuchanie & - emocjonalna obecność w dialogu z pacjentem \\
i zapamiętywanie & - wpasowanie się w kanał komunikacyjny pacjenta \\
- znajomość reguł & - okazywanie empatii i zainteresowania \\
dotyczących ko- & - okazywanie wrażliwości w wymiarze interpersonalnym \\
mentowania czy & - unikanie nadmiernej identyfikacji z sytuacją i emocjami pa- \\
wysuwania innych & cjenta \\
sugestii & - unikanie zachowań, które mogą skutkować oporem klienta \\
\hline
\end{tabular}

Opracowanie własne na podstawie: A. Golczyńska-Grondas, M. Grondas, Biographical Research and Treatment. Some Remarks on Therapeutic Aspects of Sociological Biographical Interviews, Przegląd Socjologii Jakościowej, 2017, IX, 4, s. 29-47.

Nie oznacza to, że osobą bardziej przygotowaną do prowadzenia wywiadów narracyjnych jest psychoterapeuta. Potrafi on lepiej budować relacje i w bezpieczny sposób reagować na skutki opowiadania o emocjonalnie trudnych doświadczeniach. Z kolei badacz trafniej kieruje strukturą wywiadu i z większą wprawą zyskuje orientację $\mathrm{w}$ przedmiocie badania, co nie musi prowadzić do naruszania integralności i podmiotowości narratora.

Gabriele Rosenthal rozróżnia dwa typy narratorów: takich, którzy zdołali się zdystansować do przeszłości i ustabilizować emocje oraz znajdujących się w aktywnej fazie kryzysu życiowego, a co za tym idzie - ich równowaga emocjonalna bywa zachwiana.

W pierwszym przypadku badacz-biograf może oprzeć się na rogersowskim schemacie aktywnego słuchania, facylitując retrospekcję i prosząc $\mathrm{w}$ razie potrzeby, aby narrator przypomniał sobie: ludzi, klimat, miejsca, zapachy, kolory - wszystko co pozwala pełniej rekonstruować minione wydarzenia. W drugiej sytuacji badacz musi zachować daleko posuniętą ostrożność, udzielając wszelakiego, w tym niewerbalnego, wsparcia swemu rozmówcy, aby uchronić go przed restymulacją traumy. Zagrożenie dla pozytywnie rozumianej pracy nad biografią mogą stanowić zarówno blokady, jak i uwikłanie narratora $\mathrm{w}$ przeszłość, które uwalnia silne emocje oraz zapobiega zamknięciu niedokończonych spraw i relacji ze znaczącymi Innymi. Podobne znaczenie mają: cofnięcie do przeszłości, ujawniające, jak wielu rzeczy jeszcze narrator nie wie, czy też nie rozumie ich przyczyn bądź tworzenie negatywnych skryptów w odniesieniu do samego siebie. W wyniku asymilowania deprecjonujących faktów na temat własny oraz innych osób, a także świadome lub nie obsadzanie się $\mathrm{w}$ roli ofiary innych prowadzić może nie tylko do naruszenia samooceny, ale też poczucia utraty podmiotowości ${ }^{22}$.

Zazwyczaj pierwszym etapem, a zarazem konsekwencją wywiadu narracyjnego jest praca $\mathrm{z}$ biografią, natomiast jej kontynuacją bywa praca $\mathrm{z}$ toż-

${ }^{22}$ Za: A. Golczyńska-Grondas, M. Grondas, Biographical Research and Treatment. Some remarks on Therapeutic Aspects of Sociological Biographical Interviews, Przegląd Socjologii Jakościowej, 2017, IX, 4, s. 29-47. 
samością. Praca z biografią jako wewnętrzna aktywność umysłu i psyche zmierza ku lepszemu rozumieniu siebie, odkrywaniu mechanizmów psychicznego wzrostu, poszukiwaniu alternatyw dla bieżącego działania, o ile uznamy je z nieefektywne. Praca interpretacyjna, która jest efektem przywołanych wspomnień, pozwala uporządkować myślenie o sobie, stawić czoła trudnościom i konsekwencjom tego, co wydarzyło się w przeszłości.

Praca z tożsamością stanowi z kolei pogłębienie działań biograficzno-interpretacyjnych, nierzadko jest konsekwencją uświadomionej trajektorii cierpienia. Cel pracy z tożsamością polega na skonstruowaniu i zaakceptowaniu realistycznej wizji własnej przyszłości w miejsce rozsypanego planu życia, będącego wynikiem życiowej traumy. Kluczowe jest tutaj zastąpienie złych czy niechcianych identyfikacji bardziej pożądanymi i wzmacnianie re-syntezy elementów osobowości i tych zasobów psychicznych, które pozwolą narratorowi lepiej funkcjonować w otaczającej rzeczywistości.

W większości przypadków, w wyniku podjętej pracy nad biografią, jako jej wynik i konsekwencja wcześniej czy później pojawiają się czynniki pozytywnie oddziałujące na psychikę narratora. Zaliczyć do nich można:

- uwolnienie obciążających trudnych emocji związanych z traumatycznymi doświadczeniami;

- akceptację przez badacza - biografa obecnej sytuacji i psychicznych barier narratora;

- rozwijanie samoświadomości jako konsekwencji nabywania wiedzy o możliwościach spożytkowania negatywnych doświadczeń i uczynienia ich źródłem rozwoju;

- transformację schematów poznawczych, postaw i wartości budujących jego stosunek do życia w celu osiągnięcia wyższego poziomu samoakceptacji;

- uświadomienie sobie prawdziwych emocji występujących w relacjach interpersonalnych, transformację tychże i nabywanie umiejętności zamykania niedokończonych spraw;

- bycie świadomym wewnętrznych konfliktów i zyskiwanie motywacji do tego, aby poradzić sobie $\mathrm{z}$ ich konsekwencjami, zyskiwanie wglądu we własną sytuację emocjonalną, wzbudzanie autorefleksji i gotowości do podjęcia dalszej pracy biograficznej/terapeutycznej ${ }^{23}$.

\section{Konstruowanie tożsamości a badania narracyjne}

Jak wynika z wcześniejszych rozważań, gromadzenie materiałów biograficznych w pewnym stopniu przypomina to, co dzieje się w procesie terapeutycznym. Celem terapii jest zazwyczaj wskazanie obszarów psychiki wyma-

${ }^{23}$ Tamże. 
gających wzmocnienia, stymulowanie do dokonywania zmian w myśleniu i działaniu, poszukiwanie niezbędnych do tego zasobów, a nierzadko praca nad samooceną. Konieczny etap w procesie terapii stanowi wspieranie autorefleksji pacjenta. Na tym etapie działania podejście biograficzno-narracyjne może zostać uzupełnione przez fenomenologię.

Inspirowana fenomenologią metoda wartościowania ${ }^{24}$ pozwala studiować, a następnie porządkować indywidualne doświadczenia podmiotu w sposób procesualny (nadawanie orientacji czasoprzestrzennej) oraz waloryzujący (przypisywanie innym osobom, ich uczynkom, wydarzeniom i własnym doświadczeniom określonej wagi). Wartościowanie może przebiegać na poziomie jawnym, jak również ukrytym.

W sposób jawny wpisujemy określone wydarzenia, jakie miały miejsce w naszym życiu w strukturę swojego doświadczenia, nadając mu indywidualne znaczenia. Wartościowanie ma charakter kontekstualny, bowiem zależy od wydarzeń przeszłych i ich wpływu na nasze życie oraz w jaki sposób wyobrażamy sobie następstwa przywoływanych wydarzeń. Wpływ na proces wartościowania ma nie tylko jednostkowy system aksjologiczny (decyduje o nim pewien zasób wczesnych i późniejszych doświadczeń socjalizacyjnych o względnie trwałym charakterze), ale też system wartości społeczeństwa, którego jest się członkiem - mimo to wartościowanie stanowi proces indywidualny, nie kolektywny ${ }^{25}$.

W wymiarze ukrytym, przywołując i oceniając w perspektywie czasowej swoje minione doświadczenia, odnosimy się zazwyczaj do motywów dwojakiego rodzaju - indywidualnych (potrzeba umacniania siebie) oraz prospołecznych (potrzeba afiliacji i akceptacji - jedne z kluczowych w koncepcji Abrahama Maslowa) ${ }^{26}$.

Drugą, bardzo ważną metodą przetwarzania autonarracji, a zarazem odrębnym od wartościowania procesem jest konfrontowanie z samym sobą. Poprzedza je zazwyczaj umowna zgoda na podział kompetencji między narratorem (klientem) i terapeutą (badaczem). Pojawia się tutaj jednak istotna różnica między procesem terapeutycznym a gromadzeniem materiałów (auto)biograficznych. O ile w procesie terapeutycznym ten pierwszy , ,jest ekspertem" od jawnego poziomu autorefleksji, a drugi od poziomu ukrytego, tak w komunikacji biograficznej bywa odwrotnie - to narrator wie, z czego wynikały opisywane wydarzenia i jakie mogły być ich osobiste uwarunkowania, natomiast bywa, że nie pamięta szczegółów, głównie tych, które miały

${ }^{24}$ H.J. Hermans, E. Hermans-Jansen, Autonarracje - tworzenie znaczeń.

${ }^{25}$ Do zaburzenia tego aspektu wartościowania i przekroczenia jego indywidualnego wymiaru dochodzi jednak przy próbach totalizacji świadomości jednostki - właściwą egzemplifikacją tego procesu są efekty psychomanipulacji w sektach czy innych organizacjach wywierających destrukcyjny wpływ na naszą psychikę.

${ }^{26}$ A. Maslow, W stronę psychologii istnienia, przekł. I. Wyrzykowska, Poznań 2004. 
charakter traumatyczny, a zatem sprawniej porusza się w obrębie motywów i uwarunkowań, niż w obrębie szczegółowo rozumianych elementów i chronologii swoich działań.

Metoda konfrontowania składa się z kilku etapów i ma na celu zwiększenie introspekcji, stymulowanie rozwoju samoświadomości po to, aby sformułować własny punkt widzenia na świat oraz przeżyte niegdyś wydarzenia i zestawić je z tym, jak myślimy o nich obecnie. Opowiadanie, snucie opowieści prowadzi zatem do walidacji (lub inwalidacji) tego, co jest treścią narracji, następnie do restrukturyzacji i powtórnego integrowania osoby wokół tego, co jest tworzywem opowieści. W budowaniu autobiograficznej opowieści kluczowe znaczenie mają słowa, szczególnie prowadzące do wartościowania, kreowania siebie w opisywanej sytuacji, a następnie do eksplorowania uczuć, które procesom tym towarzyszą.

Nierzadko narracja w procesie terapeutycznym generuje pytania odnoszące się do znaczenia osób, przywoływanych wydarzeń i zaistniałych okoliczności. Słowa, które wypowiadamy w takiej sytuacji mają duże znaczenie, ponieważ są kluczem do zrozumienia siebie, tego co przeżyte, umieszczenia swojej osoby i wydarzeń w określonym kontekście, konfrontowania naszych zamiarów z osiągniętymi rezultatami, integrowania swoich działań. Tym samym, pozwalają na pozytywne rozwiązanie kryzysów rozwojowych i domknięcie rozwojowego cyklu (koncepcja ośmiu faz rozwojowych Erika Eriksona) ${ }^{27}$.

\section{W stronę podsumowania}

$\mathrm{W}$ procesie terapeutycznym narracja oparta na snuciu autobiograficznej opowieści pełni funkcję sprawczą; opowiadając coś, uświadamiamy sobie powtarzalność własnych działań i reakcji, a przyglądając się ich uwarunkowaniom, z większą łatwością szukamy rozwiązań problemów, które skłoniły nas do podjęcia spotkań terapeutycznych. Pod wpływem narracji i sposobu w jaki jej treści są uwypuklane przez terapeutę (ale też innego rozmówcę prowadzącego dialog), uczymy się zwracać uwagę na pomijane we własnych refleksjach detale, a pod wpływem rozwijającej się samoświadomości zaczynamy lepiej rozumieć samych siebie, ale także innych. W taki oto sposób można opisać wspierającą funkcję narracji, nierzadko gromadzonej nie tylko w obecności słuchacza-terapeuty, ale też spisywanej w formie dziennika.

${ }^{27}$ Erik Erikson, amerykański psychoanalityk, opisuje swoją koncepcję ośmiu faz występujących w cyklu życia. Fazy te przedzielone są kryzysami normatywnymi, których pozytywne rozwiązanie pozwala na zamknięcie jednej i przejście do kolejnej (E. Erikson, Tożsamość a cykl życia, przekł. M. Żywicki, Poznań 2004). 
W polskiej tradycji psychologicznej od kilkudziesięciu lat funkcjonuje, wprowadzona przez Kazimierza Dąbrowskiego, autorska teoria dezintegracji pozytywnej, przejawiającej się dysharmonią emocjonalną, poczuciem nieadekwatności i zdekompletowania, aż po fragmentaryzację struktury osobowości ${ }^{28}$. Jak się wydaje, pojęcie to można zastosować do wielu postaci kryzysu egzystencjalnego czy rozwojowego - tutaj do sytuacji radzenia sobie z trudnymi wspomnieniami przywołanymi w sytuacji wywiadu biograficznego. Dąbrowski, w przeciwieństwie do przeważającej liczby psychologów, przypisuje dezintegracji wartość pozytywną - te same czynniki wpływające na skłonność do dezintegracji determinują bowiem możliwości aktywnego rozwoju moralnego, społecznego, czy intelektualnego także (czy nawet szczególnie) wówczas, kiedy jest to rozwój po traumie ${ }^{29}$.

Jednakże, aby można było $w$ takiej sytuacji mówić o rozwoju w znaczeniu progresywnym, konieczne jest skorzystanie z zasobów - zwanych przez Dąbrowskiego esencjami indywidualną i społeczną ${ }^{30}$ - które podlegają stymulowaniu w procesach zwanych przez Gabriele Rosenthal pracą z biografią i pracą z tożsamością. Początkiem nowego etapu, zapoczątkowanego dostrzeżeniem możliwości reinterpretacji, scalenia, odbudowania struktury psychicznej po traumie, może być każda interakcja, podczas której dochodzi do spotkania między ludźmi, wykorzystującego walory nieprzystosowania (dezadaptacji) do trudnej psychicznie sytuacji. Bowiem, spotkanie takie może właśnie poprzez dezintegrację wieść ku transcendencji, pokonaniu kryzysu oraz przekroczeniu barier utrudniających rozwój i samorealizację. Spotkaniem takim może być także właściwie przeprowadzony wywiad narracyjny.

\section{BIBLIOGRAFIA}

Bauman T., Pilch T., Zasady badań pedagogicznych: strategie ilościowe i jakościowe, Wydawnictwo Edukacyjne Żak. Warszawa 2001.

Buhler Ch., Bieg życia ludzkiego, przekł. E. Cichy, J. Jarosz, Wydawnictwo Naukowe PWN, Warszawa 1999.

Chase S., Wywiad narracyjny - wielość perspektyw, podejść, głosów, [w:] Metody badań jakościowych, t. 2, red. N. Denzin, Y. Lincoln (red. nauk. wyd. polskiego K. Podemski), Wydawnictwo Naukowe PWN, Warszawa 2009.

Czyżewski M., Socjologia interpretatywna i metoda biograficzna: przemiana funkcji. Antyesencjalistyczne watpliwości i sprawa krytyki, Przegląd Socjologii Jakościowej, 2017, IX, 4.

Dąbrowski K., Dezintegracja pozytywna, Państwowy Instytut Wydawniczy, Warszawa 1979.

${ }^{28}$ K. Dąbrowski, Dezintegracja pozytywna, Warszawa 1979, s. 11.

29 M. Haas, Niezniszczalni. Rozwój po traumie, przekł. L. Białek, Kielce 2017.

${ }^{30}$ Wśród wspomnianych esencji Dąbrowski wymienia m.in.: zainteresowania, talenty, uczucia, samoświadomość, empatię, autonomię, odpowiedzialność, autentyzm; por. K. Dąbrowski, Trud istnienia, Warszawa 1986, s. 7. 
Dąbrowski K., Trud istnienia, Wiedza Powszechna, Warszawa 1986.

Erikson E.H., Tożsamość a cykl życia, przekł. M. Żywicki, Zysk i S-ka Wydawnictwo, Poznań 2004.

Goffman E., Spotkania, przekł. P. Tomanek, Zakład Wydawniczy Nomos, Kraków 2010.

Golczyńska-Grondas A., Grondas M., Biographical Research and Treatment. Some remarks on Therapeutic Aspects of Sociological Biographical Interviews, Przegląd Socjologii Jakościowej, 2017, IX, 4.

Haas M., Niezniszczalni. Rozwój po traumie, przekł. L. Białek, Wydawnictwo Charaktery, Kielce 2017.

Hermans H.J., Hermans-Jansen E., Autonarracje - tworzenie znaczeń w psychoterapii, Pracownia Testów Psychologicznych, Warszawa 2000.

Januszewska E., Wywiad biograficzny i metoda biograficzna - perspektywa badań jakościowych, [w:] Dziecko czeczeńskie w Polsce: między trauma wojenna a doświadczeniem uchodźstwa, Wydawnictwo Adam Marszałek, Torun 2010.

Kubinowski D., Jakościowe badania pedagogiczne: filozofia, metodyka, ewaluacja, Wydawnictwo UMCS, Lublin 2010.

Kvale S., Interviews: wprowadzenie do jakościowego wywiadu badawczego, przekł. i oprac. S. Zabielski, Wydawnictwo Uniwersyteckie Trans Humana, Białystok 2004.

Lalak D., Życie jako biografia: podejście biograficzne w perspektywie pedagogicznej, Wydawnictwo Edukacyjne Żak, Warszawa 2010.

Maslow A., W strone psychologii istnienia, przekł. I. Wyrzykowska, Dom Wydawniczy Rebis, Poznań 2004.

Retter H., Komunikacja codzienna w pedagogice, przekł. M. Wojdak-Piątkowska, oprac. B. Śliwerski, Gdańskie Wydawnictwo Psychologiczne, Gdańsk 2005.

Rubacha K., Metodologia badań nad edukacją, Wydawnictwa Akademickie i Profesjonalne, Warszawa 2008.

Urbaniak-Zając D., Biograficzna perspektywa badawcza, [w:] Uczenie się z biografii innych, red. E. Dubas, W. Świtalski, Wydawnictwo Uniwersytetu Łódzkiego, Łódź 2011.

Urbaniak-Zając D., Kos E., Badania jakościowe w pedagogice: wywiad narracyjny i obiektywna hermeneutyka, Wydawnictwo Naukowe PWN, Warszawa 2013.

Znaniecki F., Metoda socjologii, Wydawnictwo Naukowe PWN, Warszawa 2008. 